Motivating compliance behavior among offenders: Procedural justice or deterrence?

\author{
Kristina Murphy, Griffith University \\ Ben Bradford, University of Oxford \\ Jonathan Jackson, London School of Economics \\ In press at Criminal Justice and Behavior
}

\author{
Corresponding author: \\ Kristina Murphy \\ Griffith Criminology Institute \\ Griffith University, Mt Gravatt Campus, QLD, 4122, Australia \\ t.murphy@griffith.edu.au \\ Ph: +61 737351092
}

\title{
Author acknowledgements
}

We would like to acknowledge the funding support from the Australian Research Council (Grant Number DP0987792). We would also like to thank two anonymous reviewers for their thoughtful suggestions and reflections on an earlier version of this paper.

\section{Author biographies}

Kristina Murphy is an Associate Professor in the School of Criminology and Criminal Justice and in the Griffith Criminology Institute at Griffith University, Australia. Her research explores how procedural justice shapes attitudes and behaviors across different population groups and across different regulatory contexts.

Ben Bradford is Department Lecturer in Criminology at the Centre for Criminology, University of Oxford. His work revolves around procedural justice theory and aspects of operational policing.

Jon Jackson is a professor of research methodology at the London School of Economics. His research focuses on public attitudes towards crime and the criminal justice system. 
Motivating compliance behavior among offenders: Procedural justice or deterrence?

\begin{abstract}
Research shows that procedural justice can motivate compliance behavior through the mediating influence of either legitimacy or social identity. Yet few studies examine the relative importance of these two mediators in the same analysis. Using three waves of longitudinal survey data collected from 359 tax offenders we examine: (a) whether procedural justice is important to offenders' decisions to comply with their future tax obligations over and above fear of sanctions; and (b) whether legitimacy and social identity processes mediate the relationship between procedural justice and compliance. Our results reveal that: (1) legitimacy mediates the effect of procedural justice on compliance; (2) social identity mediates the procedural justice/compliance relationship; (3) identity seems to matter slightly more than perceptions of legitimacy when predicting tax compliance; (4) perceived risk of sanction plays a small but counterproductive role in predicting tax compliance. We conclude that normative concerns dominate taxpayers' compliance decisions. Our findings have implications for understanding compliance behavior, but also for conceptualizing why and how procedural justice can motivate such behavior.
\end{abstract}




\section{Introduction}

There are many reasons why people obey laws. For some, compliance is instrumental in nature - it is motivated by fear of consequences should they be detected violating a law. For others, law-abiding behavior is elicited by an intrinsic motivation to follow rules because of the belief that it is right to do so. On this account, compliance is motivated by normative concerns, such as seeing one's self as a lawabiding citizen or holding a corresponding belief in the legitimacy of the authority enforcing those laws. In this paper we contrast the instrumental versus normative perspectives of compliance. We do so in a context where non-compliance has been found to be rife - the taxation context (Braithwaite; 2003; Braithwaite, Schneider, Reinhart \& Murphy 2003). We draw on three waves of survey data collected from taxpayers who have been caught and punished for serious tax evasion to examine which of the motivators of compliance best captures their willingness to comply with tax laws in the future. Before proceeding to discuss our findings we first provide a review of the literature.

\section{Motivating compliance: Deterrence or procedural justice?}

Many regulatory and criminal justice systems are based on the premise that individuals are rational actors, driven to comply with laws and regulations out of fear of the consequences for doing otherwise. This instrumental, or deterrence-based, perspective of human behavior suggests that individuals weigh up the costs and benefits associated with obeying the law (Allingham \& Sandmo 1972; Gibbs 1968; Tittle 1969). If the costs of non-compliance outweigh the benefits associated with compliance then the rational choice will be to comply with the law. In contrast, if the benefits associated with noncompliance outweigh the potential costs then non-compliance will be the rational choice. Advocates of this perspective suggest that non-compliance will be viewed as the risky choice if: 1) the risk of detection for non-compliance is high; 2) the severity of sanctions associated with rule-breaking is high; and 3) non-compliance is dealt with swiftly by authorities (Becker 1968). Proponents of the instrumental perspective therefore suggest that non-compliance can be deterred by increasing both the probability of detection for wrong-doing and the severity of sanctions should wrong-doing be detected.

On balance, however, research suggests that increasing the severity of potential punishments will have limited effect (Doob \& Webster 2003; Pratt, Cullen, Blevins, Daigle \& Madensen 2008). Rather, increasing the probability of detection has been found to have greater success in deterring would-be offenders from violating laws (Andreoni, Erard \& Feinstein 1998; Nagin 2013). Yet, in many regulatory contexts the probability of being caught and punished for violating rules and laws is low. In the taxation context, for example, the probability of being detected evading taxes is extremely low. Estimates from the US and Australia indicate that fewer than 5\% of the population have their tax affairs audited in any one year (Marshall, Smith \& Armstrong, 1997; Slemrod, Blumenthal \& Christian 2001). In such a context, the actual risk of detection for non-compliance is unlikely to substantially influence an individual's decision to comply with their legal obligations. What regulators rely on, therefore, is regulatees perceiving the risk of detection and sanction to be high. In fact, research has found that individuals can also be strongly deterred from committing criminal acts if they perceive legal sanctions to be certain, swift or severe (Williams \& Hawkins 1986).

Studies show that risk perceptions can be influenced by personal experience. For example, Paternoster and Piquero (1995) argue that if someone offends but is not detected or punished for the offence, then their perception of sanction risk will fall. Anwar and Loughran (2011) likewise suggest that if one were to be sanctioned for an offence, or see someone else being sanctioned, their perceived risk of being detected and sanctioned will be enhanced. But Anwar and Loughran also argue that persistent offenders can respond differently to deterrence. They showed empirically that serious offenders who had been arrested numerous times in the past were less concerned with sanction risk than less persistent or less serious offenders. In short, an individual's offending experiences can affect their risk perception and response to that perception.

Actual and perceived risk of sanctions can also indirectly affect law-abiding behavior through the perceived informal sanctions they can elicit. Grasmick and Bursik (1990) argue that shame emotions imposed by significant others can contribute to the effectiveness of deterrence measures. This is because the negative judgment of significant others matters more to an offender (Akers 1994). Anderson, Chiricos and Waldo (1977) identified that informal networks (e.g., family or neighborhood structures) indeed had a stronger impact on deterring wrong-doing than actual or perceived deterrence imparted by the state. Such informal sanctioning can therefore have a multiplicative effect on deterring offences.

While the deterrence literature has a long history, an alternative perspective that attempts to explain people's compliance behavior is the procedural justice perspective. Procedural justice theory is 
premised on a different account of offending behavior - one that can provide an explanation as to why people comply with the law even if there might be little actual or perceived chance they will be detected breaking laws. Tyler (1990) has argued that legal authorities can promote law-abiding behavior through utilizing procedural justice in their dealings with the public. Tyler has consistently found that if authorities are neutral in their decision-making, if they treat people with fairness, dignity and respect, and provide citizens with an opportunity to voice concerns to authorities (i.e., all elements of procedural justice) then people will view that authority as more morally appropriate and entitled to be obeyed; that is, they will view the authority as more legitimate. Tyler also shows that people will be less likely to violate laws if authorities are viewed as legitimate (Tyler 1990; see also Murphy, Tyler \& Curtis 2009; Jackson et al. 2012a). Tyler (2006) argues that people who believe that authorities are the rightful holders of power (i.e., that they have legitimacy) will be more likely to be law-abiding because they internalize the moral value that it is right and just to obey those authorities and the law.

A rapidly growing number of procedural justice studies conducted across different countries, regulatory contexts, and population groups have found that such normative-based concerns seem to be the more powerful force for predicting people's compliance behavior. For example, in the USA, Sunshine and Tyler (2003) found that New Yorker's perceptions of police legitimacy were shaped predominantly by whether they viewed police as procedurally just. Perceptions about the effectiveness of police to deter and prevent crime were less important. These perceptions of legitimacy went on to positively influence New Yorker's self-reported compliance with the law. Similarly, Reisig, Tankebe and Mesko's (2014) study in Slovenia showed that procedural justice was also the main predictor of police legitimacy, which in turn was linked to self-reported compliance behavior. Importantly, procedural justice in their study was found to be the more important predictor of compliance than deterrence concerns (see also Bradford, Hohl, Jackson \& MacQueen 2015; Mazerolle, Antrobus, Bennett \& Tyler 2013; Mazerolle, Bennet, Antrobus \& Eggins 2012; Reisig, Bratton \& Gertz 2007; Tankebe 2009). A small number of studies have also examined the link between procedural justice and compliance using offender samples. For example, Paternoster, Brame, Bachman and Sherman (1997) found that domestic violence perpetrators were less likely to reoffend after being arrested if they perceived the police officers that arrested them to be procedurally just. Papachristos, Meares and Fagan (2012) also found that violent offenders were less likely to report carrying a gun if they viewed police as legitimate and if they viewed police to be using procedural justice (for research with adolescent offenders see Piquero et al 2005; Gau \& Brunson 2010). Finally, in an observational study, McCluskey, Mastrofski and Parks (1999) found that misbehaving citizens were more likely to acquiesce to the commands of police officers if they viewed police to be using procedural justice during the encounter.

Research in non-policing contexts has revealed similar findings. For example, Reisig and Mesko (2009) studied prisoners in Slovenia, and found that their perceptions of procedural justice within the prison were positively associated with both self-reported and actual records of compliance in prison (see also Brunton-Smith \& McCarthy, 2015). In a study of corporate compliance, Braithwaite and Makkai (1994) revealed that nursing home managers were more likely to comply with regulatory standards if they felt nursing home inspectors had previously treated them with procedural justice. Those managers who felt that inspectors had used heavy-handed deterrence threats were less compliant in a follow-up inspection.

Procedural justice theory has also been applied successfully to understand tax compliance behavior. Murphy (2005), for example, revealed that procedural justice imparted by a tax authority strongly predicted tax offenders' perceptions of the legitimacy of the tax authority, which in turn influenced tax offenders' self-reported compliance behavior; those who viewed the Tax Office as more legitimate were less likely to report evading taxes. Interestingly, there was no relationship between offence history and subsequent tax non-compliance in Murphy's (2005) study, suggesting that prior sanction experience played no deterrent role in subsequent compliance behavior. Similar findings have been obtained when examining actual tax compliance behavior. In a randomized controlled trial, Wenzel (2006) found that tax offenders were significantly more likely to comply with the tax authority's request for compliance, and were less likely to complain about their treatment, if they received correspondence from the Tax Office that emphasized procedural justice messages. Taxpayers who received standard correspondence from the tax authority (i.e., the letter emphasized sanctions for non-compliance) were more likely to make complaints and were less likely to comply with the tax authority's request (see also Wenzel 2004).

In summary, the above-mentioned studies represent only a sample of those that have found a positive link between procedural justice, legitimacy, and compliance. What they show is that procedural justice seems to be more important than deterrence in predicting compliance behavior. 


\section{Legitimacy and social identity as important mediating variables}

One important aspect of procedural justice theory is the role that legitimacy plays in the procedural justice/compliance relationship. Numerous empirical studies have demonstrated that an authority's legitimacy is an important mediating factor in the procedural justice/compliance relationship (e.g., Tyler 1990; Sunshine \& Tyler 2003; Reisig et al 2014). This relationship is important because it suggests that people feel compelled to comply with laws if they view the authority enforcing the law to be legitimate. When citizens recognize the legitimacy of an authority they believe that the authority has the right to prescribe and enforce law-abiding behavior. This results in a corresponding obligation to bring one's behavior into line with what is expected under the law. Hence, authorities can best motivate compliance behavior through building public perceptions of their legitimacy. Legitimacy is best promoted when authorities use procedural justice with citizens.

We examine whether legitimacy mediates the statistical effect of procedural justice on compliance, but we also examine whether social identity is a mediating factor. Social psychologists have attempted to explain why procedural justice might have the positive effects that it does. These scholars argue that the exercise of fair treatment by an authority strengthens the social bonds between those in power, those they have power over, and the broader social group to which both belong. In other words, procedurally just treatment promotes an individual's social identification with the power holder and the group that the power holder represents (Tyler \& Blader 2003; Huo 2003; Huo, Smith, Tyler \& Lind 1996; Bradford 2014; Bradford, Murphy \& Jackson 2014; Bradford, Hohl, Jackson \& MacQueen, 2015; Murphy 2013; Murphy, Sargeant \& Cherney 2015).

Identification can take many forms and people often identify with many different groups, sometimes simultaneously. For example, one can identify as being a mother, an Australian, as a member of an ethnic or racial minority group, or as a law-abiding citizen. The context matters and will determine which identity becomes prominent in that situation. According to social identity theory (Tajfel \& Turner 2001), strong identification with a particular group will activate the roles, norms and responsibilities expected of an individual within that group. In a law enforcement context, adhering to the group's norms may include obeying the laws of the group, respecting authorities, and being a law-abiding citizen in that group. Group norms relate to the moral norms that would be expected of people in society.

Key to this identity-based argument is the idea that procedural justice communicates to people information about their status and value within society. Being held in good standing encourages one to align one's beliefs and behavior with the wider group. It also encourages people to support and work with groups they identify strongly with. In other words, identification will motivate law-abiding behavior because members of social groups are motivated to behave in ways that are expected of them from other group members and because they draw value, status and self-worth from these roles and relationships (Tajfel \& Turner 2001). This process suggests that people internalize the norms and values of the group to which they belong; regarding a group authority as legitimate and abiding by the laws of that group are two such norms that are expected of group members (Horne 2009).

The Group Engagement Model (Tyler \& Blader 2003) specifically proposes that procedural justice can shape and strengthen social identification with a group, which results in greater propensity to comply with the groups' norms and rules. Social identity in the Group Engagment Model therefore mediates the relationship between procedural justice and people's attitudes and behaviors. This perspective also suggests that social identities are changeable over time depending on the type of treatment one receives from a group representative. Fair treatment can enhance social identification while unfair treatment can diminish social identification. We adopt this account for thinking about the relationship between procedural justice, social identity and subsequent behavior. We propose that tax authorities (like other authorities) have the capability to influence the law-abiding identities of those they come into contact with through the way in which they treat them (c.f., Bradford 2014; Bradford et al 2014; Blackwood, Hopkins \& Reicher 2013). We also suggest that these law-abiding identities can directly influence taxpayers' propensity to comply with legal rules (c.f., Bradford et al 2015).

Such suggestions are not dissimilar to arguments put forth by labelling theories. Labelling theories argue that negative system contact can result in delinquency, just as positive system contact can result in diminished offending (e.g., McAra \& McVie 2007; Wiley \& Esbensen 2013). According to labelling theories this occurs because system contact has the potential to stigmatize individuals and promote delinquent identities (Braithwaite 1989); these delinquent identities in turn result in individuals rejecting mainstream values and norms, which can lead to the potential for re-offending. We suggest that procedurally unfair treatment experienced during system contact has the potential to stigmatize 
individuals and reduce law-abiding identities, which will loosen the social bonds that promote lawabiding behavior.

Finally, identities may also directly influence compliance behavior because those who identify more strongly with a group will place greater weight on ensuring the outcomes of their group are favorable (Bradford et al 2015). Not paying one's taxes, while beneficial to an individual, is likely to be detrimental to the group as a whole; fewer taxes mean fewer resources that can be distributed to the group to pay for public goods. Strong identification with a group is thus likely to promote the groups' interests. This includes alignment with the expected roles and obligations of the group, and compliance with the group's laws.

\section{Present Study}

The overarching aim of this study is to examine how normative and instrumental concerns motivate tax offenders' decisions to comply with their subseqent tax obligations. We also aim to examine whether social identity and offenders' perceptions of the tax authority's legitimacy each mediate the effect of procedural justice on compliance behavior, and explore which proves to be the more important mediator. The taxation context is interesting to examine because of the widely held assumption that taxpayer behavior is most likely driven by instrumental concerns. If normative concerns are found to dominate tax offenders' decision to comply with their tax obligations in the future, over and above their concerns about being sanctioned, then this provides convincing evidence regarding the widespread applicability of the normative model of compliance.

The theoretical innovation of our study is to study the importance of social identity processes in the context of a procedural justice account of compliance. This focus is a relatively under-explored aspect of procedural justice theory (in the criminology context at least) and thus allows us to test the relative importance of social identity to explaining compliance behavior. Of particular interest is to test the relative importance of identity versus legitimacy as a predictor of compliance behavior. Based on our review of the literature, we test three main hypotheses:

H1) Normative concerns (i.e., legitimacy; identity) will more strongly predict tax compliance behavior than perceived risk of sanction.

H2) Perceptions of legitimacy will mediate the effect of procedural justice on tax compliance behavior.

H3) Social identity will mediate the effect of procedural justice on tax compliance behavior.

\section{Sample and Procedure}

\section{Methods and Data}

We use three waves of survey data collected over a period of six years from the same tax offenders. The fact that we have three waves of survey data is a strength of our study. Most studies in the procedural justice literature rely solely on cross-sectional survey data. The causal relationships between variables cannot be ascertained in such studies. With longitudinal data we will be able to demonstrate whether perceptions of procedural justice experienced during a sanctioning event predict a strengthening (or diminishing) of a law-abiding identity and perceptions of the Tax Office's legitimacy over time, and whether these variables in turn predict subsequent tax compliance behavior over and above perceptions of deterrence. One's ability to make causal claims is strengthened somewhat with longitudinal data because, in such a research design, confounders must be time-varying, intra-individual factors.

All of our respondents had been caught and sanctioned for involvement in aggressive tax avoidance schemes (it was the first tax offence for $43 \%$ of our sample; see Murphy 2003). To undertake the study it required working closely with the Australian Tax Office (ATO) to draw the sample. Given privacy legislation in Australia prohibits individuals outside of the ATO having access to the names and contact details of tax offenders, the ATO drew a random sample of 6,000 of the 42,000 known taxpayers involved (sampling was stratified by State and Territory jurisdiction across Australia). The ATO sent correspondence to the sample, inviting them to participate in the study. Respondents were advised to return their completed survey to the first author's University address. A series of reminder letters was sent by the ATO to non-responsive taxpayers over six months. A total of 2,301 taxpayers returned a completed survey, and after adjusting for taxpayers who were not contactable (did not live at the address listed in the ATO's database; $\mathrm{N}=677$ ), a response rate of $43 \%$ was achieved. The representativeness of 
the sample was confirmed by comparing both the gender and state of residence of survey respondents to the overall offender population in the ATO's database (Murphy \& Byng 2002) ${ }^{1}$.

Respondents were asked if they would be willing to participate in future research. 1,250 wave 1 respondents agreed, and provided their name and contact details direct to the first author. Two years later, these respondents were sent an invitation to participate in wave 2 of the study. 659 taxpayers returned a completed wave 2 survey. Adjusting for people who were no longer contactable at wave 2 $(\mathrm{N}=146)$, a wave 2 response rate of $60 \%$ was achieved (Murphy \& Murphy 2010). Finally, four years after the wave 2 survey was completed, the original 1,250 respondents who agreed to be followed-up at wave 1 (minus those who were not contactable at wave $2 ; \mathrm{N}=146$ ) were recontacted again and invited to participate in the final wave of the study. For the 1,112 taxpayers recontacted at wave 3, 478 completed surveys were received. Adjusting for those no longer contactable at wave $3(\mathrm{~N}=178)$, a wave 3 response rate of 52\% was achieved (Murphy, Murphy \& Mearns 2010).

The data utilized in the present study relates to survey responses from taxpayers who participated in all three waves $(\mathrm{N}=379)$. For the final sample of 379 respondents, $84 \%$ were men, the average age of respondents was 49.40 years $(\mathrm{SD}=8.47$ years; age range $=25$ to 72$), 47.5 \%$ had a university degree; $87 \%$ were in employment, and $83 \%$ were married. The average annual income for respondents was $\mathrm{A} \$ 87,830(\mathrm{SD}=\mathrm{A} \$ 47,750)$.

\section{Survey instrument and measures}

Confirmatory Factor Analysis (CFA) using Mplus 7.1 was used to construct and validate the measures used in the current paper. Table A1 shows the question wordings and factor loadings for each concept. It also presents the means and standard deviations for each latent variable. The Cronbach alpha scores and model fit statistics for the CFA reveal that all factors and scales, except the legitimacy scale, were strong and reliable (the RMSEA score was less than 0.05; the TLI and CFI scores were greater than 0.95). The factors were: (a) procedural justice (wave 1); (b) ATO legitimacy, stigmatization, social identity, personal taxpaying morality (wave 2); and (c) self-reported tax compliance (wave 3). All measures were recorded on a 1 (strongly disagree) to 5 (strongly agree) Likert scale. Perceived risk of sanction for tax offending (wave 2) was measured on a 1 ( $0 \%$ chance of being caught) to 5 (100\% chance of being caught) scale. Bi-variate correlations between these scales and variables are presented in Table A2. Note that all latent variables (except stigmatization) were coded such that a higher score indicated more favorable responses (i.e., more procedural justice; more legitimacy; etc). Higher stigmatization scores indicated taxpayers felt more stigmatized. Each latent variable was calculated by summing the responses to each scale question and dividing by the number of survey items in that scale. Missing data for our measures was handled through MPlus using the maximum likelihood estimation procedure to replace missing values. Only cases with no responses were excluded. Missing data were typically low, with less than $1 \%$ missing data for most attitudinal questions.

The procedural justice scale was measured via a 10-item scale that assessed taxpayers' perceptions of the ATO's use of procedural justice (the four procedural justice elements of neutrality, fairness, respect and voice were measured). The 4-item ATO legitimacy scale reflected taxpayers' feelings of obligation to follow the directives of the ATO and the degree of respect they had for the ATO. We acknowledge the recent debate regarding the legitimacy concept in the procedural justice literature (e.g., Bottoms \& Tankebe 2012; Jackson \& Gau 2015; Tankebe 2013; Tyler \& Jackson 2013, 2014). These scholars have recently suggested that legitimacy scales that measure obligation to obey and confidence in authority can be limited. They suggest that additional measures should be included to produce a more well-rounded measure of legitimacy. For example, these additional measures might include questions about the perceived legality of an authority (i.e., do authorities follow the rules themselves?) and normative alignment (i.e., do authorities share the same values as citizens and exercise their authority in normatively appropriate ways). Unfortunately, our legitimacy measure does not fully capture these additional aspects of legitimacy due to the fact that our data was collected before these debates were presented in the literature. We instead utilize a legitimacy measure commonly used and cited in earlier research (Tyler 1990). Future researchers may wish to replicate our findings with a more sophisticated measure of legitimacy. But even with this measure we find legitimacy mediates the effect of procedural justice on compliance as has been demonstrated consistently in the literature with both the old and new measure (see Results below).

\footnotetext{
${ }^{1}$ The ATO only provided the proportion of men and women in the tax offender population and the proportion of taxpayers who lived in each of the seven states and territories of Australia.
} 
The social identity scale contained 4-items, measuring strength of identification with being a member of the community of law-abiding Australian citizens. Stigmatization was another measure of identity, specifically assessing how negative system contact had labeled tax offenders with a deviant identity; it comprised 7-items. Taxpayer morality was measured with 4-items gauging how wrong taxpayers felt it was to evade taxes. This item was included given the social identity literature suggests that identification with a group activates the roles and responsibilities expected of an individual in that group (Bradford et al 2014). Personal morality has also been found to be a correlate of offending behavior so it is important to include it in a model predicting compliance (Reisig et al 2014; Tyler 1990). Risk of sanction was a 1-item question assessing respondents' perceptions of the likelihood of being caught evading taxes.

Our dependent measure was compliance. Compliance was a 6-item measure assessing taxpayers' self-reported compliance behavior. Taxpayers were asked to answer these questions by reflecting on how they felt their enforcement experience had affected their subsequent taxpaying behavior. We acknowledge a limitation of our study in that we only measured self-reported compliance behavior. However, past research does show a link between intentions to comply and actual compliance behavior (Ajzen 1985), and research conducted in other legal contexts shows that procedural justice is similarly related to both self-reported and actual compliance behavior (e.g., Reisig \& Mesko 2009).

\section{Results}

Figure 1 shows a Structural Equation Model (SEM) that allowed simultaneous testing of all our research hypotheses when predicting compliance. Structural equation modelling was used because it allows simultaneous testing of all inter-relationships between variables in the model; regression is unable to do this. The model fit statistics show that the constructed model provides a good fit to the data (RMSEA scores are below 0.05; TLI and CFI are both greater than 0.95). In this model, respondents' assessments of the ATO's use of procedural justice in the immediate aftermath of being sanctioned by the ATO (measured at Time 1) is the ultimate explanatory variable; the ultimate response variable is self-reported tax compliance behavior measured at Time 3 . The other variables constitute potential mediators of the procedural justice to compliance pathway, crucially measured at Time 2 . We can therefore model directly the temporal ordering always implied in studies of procedural justice (i.e., procedural justice $\rightarrow$ legitimacy $\rightarrow$ compliance; procedural justice $\rightarrow$ identity $\rightarrow$ compliance) but usually represented by data collected at one, or at best two, points in time.

\section{[insert Figure 1 about here]}

As can be seen in Figure 1, procedural justice had a statistically significant direct relationship with three variables in the model. Those who felt the ATO was more procedurally just at Time 1 were more likely to view the ATO as legitimate, were more likely to identify strongly as a law-abiding Australian citizen, and were less likely to feel stigmatized by the ATO at Time 2.

There was a moderately strong path from social identity to offending at Time 3 and also from legitimacy to offending at Time 3. Stronger identifiers were more likely to say they had complied with their tax obligations, and those who viewed the ATO as more legitimate were more likely to report being compliant. The perceived risk of sanction variable at Time 2 also predicted compliance at Time 3 . However, the relationship was in the opposite direction to that expected. Respondents who thought there was a greater chance they would be detected violating tax laws were less likely to report being compliant; deterrence seems to have a counter-productive effect in our model. Importantly, normative concerns seemed to have a stronger effect in predicting compliance than perceived risk of sanction (Hypothesis 1 supported). Finally, the indirect statistical effect of procedural justice on compliance was positive and significant $(\beta=0.10, p<.04)$. Those who thought the ATO was more procedurally just at Time 1 were more likely to report being compliant at Time 3 . The fact there was no direct path between procedural justice and compliance suggests that the effect of procedural justice on compliance was mediated through both legitimacy and social identity (support for Hypothesis 2 and 3). Figure 1 also shows that $25 \%$ of the variation in compliance scores can be explained by all of the included variables in the model.

Some additional relationships in our model are worthy of mention. Although not the primary focus of our study, our model reveals that these relationships are important to further our understanding of why procedural justice promotes compliance through identity and legitimacy. The stigmatization variable had an independent and significant effect on legitimacy; those who felt more stigmatized by their enforcement experience were less likely to view the ATO as legitimate. Interestingly, stigmatization was positively (not negatively) associated with the social identity variable. Those who felt more stigmatized by the ATO were more likely to identify strongly as a law-abiding Australian. There 
was also a strong association between social identity and personal taxpaying morality. Respondents who identified more strongly as a law-abiding Australian were more likely to view tax avoidance as morally wrong. The strongest predictor of compliance was the personal morality variable. Those who felt it was morally right to pay tax were more likely to say they were compliant with their tax obligations. Morality was also found to partially mediate the social identity and compliance relationship.

\section{Discussion}

The current study aimed to test whether taxpayer offenders' decisions to comply with their subsequent tax obligations were predicted more strongly by normative concerns than concerns about being caught for non-compliance. We found that it did, providing support for Hypothesis 1 . We also tested whether legitimacy and social identity mediated the relationship between procedural justice and compliance. Again, we found that they both did, supporting Hypotheses 2 and 3.

Specifically, we found that perceptions of procedural justice predicted respondents' perceptions of the legitimacy of the ATO; this relationship replicates findings observed in other legal contexts (e.g., Reisig et al 2014; Sunshine \& Tyler 2003). The experience of procedural justice during enforcement also predicted stronger levels of social identity; specifically, procedural justice was associated with lower feelings of stigmatization (i.e., deviant identity) and higher levels of identification as a law-abiding Australian. These findings also support other studies in the literature (e.g., Bradford et al 2014; Murphy \& Harris 2007).

With respect to self-reported offending, taxpayers who perceived a greater chance of being caught for engaging in tax evasion were actually less likely to say they had complied with their tax obligations. Also predicting compliance was legitimacy, social identity, and personal taxpaying morality. Those taxpayers who viewed the ATO as more legitimate, who identified more strongly as a law-abiding Australian, and who believed taxpaying was morally right, were more likely to report higher levels of compliance. These three factors had stronger effects on compliance than the perceived risk of sanction, with personal morality having the strongest effect on compliance behavior. Again, these findings support prior research conducted in other contexts, and show the specific importance of personal morality as an informal inhibitor of criminal behavior (Bradford et al 2015; Tyler 1990; Reisig et al 2014).

Importantly, the results show that both legitimacy and social identity are mediators in the procedural justice compliance relationship. Feelings of stigmatization were also found to play an indirect role in predicting compliance through taxpayers' perceptions of legitimacy and through their identification as law-abiding Australians; higher levels of stigmatization were associated with lower levels of perceived legitimacy and higher levels of social identity. Considered together, all of these findings suggest that both instrumental and normative concerns shape taxpayers' decisions to re-offend, but normative concerns were more prominent.

We should acknowledge a limitation of our study. Participant attrition in longitudinal research studies is a concern for social scientists because loss of certain participants may result in subsequent data collection phases becoming increasingly biased. Attrition may therefore lead to unreliable conclusions (Ahern \& LeBrocque 2005; Farrington 1991). For example, the ultimate dependent variable in our study is self-reported compliance behavior at time 3 . One might argue that people who are more law-abiding might be more inclined to participate in all three phases of the research. This may skew our results toward more compliant responses at time 3 . In order to explore this possibility, we compared our wave 3 and wave 1 respondents on a number of demographic and compliance questions measured at time 1. We found that the two groups did not differ on income level, educational status, gender, English speaking status, or perceived risk of sanction for non-compliance. We did, however, find a small age difference, with older people being slightly more likely to continue participation in the study over time. Interestingly, we also found that those who participated in wave 3 reported being slightly more non-compliant in the past. This latter finding in particular suggests that our wave 3 sample is slightly biased towards non-compliance. Our findings must therefore be considered with this in mind. However, the bias toward non-compliance does suggest that if normative factors can positively influence compliance behavior for more serious offenders then this highlights the virtue of authorities considering procedural justice in their disciplinary approach with offenders.

\section{Implications for theory and regulatory practice}

Deterrence-based theories of compliance suggest that individuals are primarily motivated to comply with laws due to a fear of consequences for doing otherwise. Yet, our results suggest that even in a context where one might expect instrumental concerns to dominate, individuals seem to be motivated to comply 
out of an intrinsic motivation to do so. Our respondents all had large tax debts as a result of their previous non-compliance, and they had all been through an enforcement process. Such experiences are likely to enhance peoples' perceptions that they will be caught again if violating tax laws (this suggestion is supported by the high mean score for the risk of sanction variable - see Table A1). However, this enhanced perceived risk of sanction played only a small role in predicting subsequent compliance behavior. In fact, our deterrence variable seemed if anything to have a counterproductive effect on compliance behavior. Those with more fear of being caught reported more non-compliance. This finding supports previous research showing that deterrence strategies that are perceived to be unreasonable can result in backlash and further non-compliance in the long term (Kagan \& Scholz 1984). But they also provide support for Anwar and Loughran's (2011) suggestion that serious offenders can respond differently to deterrence than less serious offenders. A more thorough investigation in the future of how serious tax offenders respond to deterrence, based on their sanction history, would be worthwhile.

Our findings point to the importance of social identities and personal morality in promoting law-abiding behavior. In fact, we found that social identity strongly mediated the effect of procedural justice on compliance. We know from other taxation research that people's connections to others do matter; what others in one's group think about taxpaying can strongly influence people's own views and behaviors. Wenzel $(2004,2005)$, for example, found that if individuals thought other taxpayers paid their fair share of taxes, and saw taxpaying as worthwhile, they themselves were more likely to see taxpaying as morally right. We propose compliance is likely to benefit as a result of strong identification with lawabiding groups because people are motivated to align their behavior to the group's norms and to act in the interests of the group they belong to. When identification with 'Australianness' and being 'lawabiding' in this group is strong, propensity to engage in activities that might harm others in the group diminishes (c.f., Bradford et al 2015). In other words, people pay their taxes because of the belief it will benefit their group.

This may partly explain why social identity and personal morality prove to be more important predictors of tax compliance behavior than perceptions of the ATO's legitimacy. Legitimacy has been linked to compliance behavior in past research by suggesting that the legitimation of legal authorities encourages internalization that it is right to obey the law because it is the law (e.g., Tyler 1990; Reisig et al 2007; Murphy, Hinds \& Fleming 2008), and we did find that legitimacy mediated the effect of procedural justice on compliance. Yet in our study social identity seemed to play a more important role in predicting compliance than did legitimacy. We suggest that strong group identification promotes a sense of obligation to behave in the interests of the group (c.f., Tajfel \& Turner 2001; Tyler \& Blader 2003).

It is worth underlining, however, that legitimacy did still have a unique statistical association with compliance. Even when controlling for personal morality and social identity levels, those who granted the ATO more legitimacy were more likely to say they complied with tax laws. Our findings therefore concur with the idea that legitimacy motivates a 'sense of duty', whereby one is motivated to comply with the laws mandated by an authority, not because one believes them to be the right, or because one wishes to avoid behavior harmful to other group members, but because one believes that following the dictates of legitimate authority is the right thing to do in and of itself.

Before concluding, we were somewhat surprised that feeling stigmatized resulted in a more positive social identity and thus, overall, a positive association with compliance. Labelling theorists would predict the opposite, with deviant identities hypothesized to result in distancing from the norms of mainstream society (Braithwaite 1989). While our finding may be an anomaly, we suggest it could also be explained by the nature of the offending behavior exhibited by our taxpayers. The majority of our respondents argued they had become involved in tax avoidance schemes on the advice of tax specialists (see Murphy 2003). They claimed their purpose for 'investing' in tax schemes was not to defraud the tax system, but to provide an investment strategy for their future. They viewed their tax advisors were to blame for their situation. If we take these claims at face value, it is perhaps not surprising to observe that feeling stigmatized during an enforcement process might result in a stronger affirmation of an honest taxpaying identity. Procedurally unfair treatment might challenge taxpayers' identity as an law-abiding citizen. Rather than create a deviant identity that results in further re-offending, however, in order to 'save face' and protect this sense of self as law-abiding, the resulting action is to communicate to others that they are 'upstanding citizens', resulting indirectly in greater self-reported compliance. Such a process is not totally foreign to criminologists. Sykes and Matza's (1957) research on how offenders attempt to neutralize their offending behavior to protect their reputation is but one example. Whether 
similar effects to ours can be found for other types of tax offenders or in other regulatory contexts remains to be seen.

\section{Conclusion}

Our results show that tax authorities should not rely solely, or even primarily, on deterrence-based strategies to ensure taxpayer compliance. Our findings suggest that enforcement strategies that speak to taxpayers' normative concerns may prove more successful for promoting voluntary tax compliance behavior in the long term. These findings support conclusions drawn by many procedural justice studies in the literature, and suggest that the procedural justice framework examined in our tax study can be generalized across different legal contexts. Our findings in particular point to the role that social identity and legitimacy plays in explaining why procedural justice has a positive effect on compliance-related behavior. If authorities wish to promote compliance with their laws and directives, procedural justice seems to provide an effective means to achieve this. This is because procedural justice generates both legitimacy and forges social bonds between individuals and the group to which the authority represents. This in turn motivates people to bring their views and behavior into line with the expectations of the group. The legitimacy of authorities is important for fostering compliance behavior, but our findings suggest that social identity may be an equally important mediating mechanism that explains why procedural justice promotes an intrinsic motivation to be law-abiding. More work is needed in this space, but future research may reveal that social identity processes are more important in procedural justice theory than has previously been suspected. 


\section{References}

Ahern, K. \& LeBrocque, R. (2005). Methodological issues in the effects of attrition: Simple solutions for social scientists. Field Methods, 17, 53-69.

Ajzen, I. (1985). From intention to action: A theory of planned behavior. In J. Kuhl \& J. Beckmann (eds). Action control: From cognition to behavior (pp11-39). Springer.

Akers, R. (1994). Criminological Theories: Introduction and Evaluation. Los Angeles, California: Roxbury Publishing.

Allingham, M. \& Sandmo, A. (1972). Income tax evasion: a theoretical analysis. Journal of Public Economics, 1, 323-338.

Anderson, L., Chiricos, T. \& Waldo, G. (1977). Formal and Informal Sanctions: A Comparison of Deterrent Effects. Social Problems, 25,103-114.

Andreoni, J., Erard, B. \& Feinstein, J. (1998). Tax compliance. Journal of Economic Literature, 36, 818860.

Anwar, S. \& Loughran, T. (2011). Testing a Bayesian learning theory of deterrence among serious juvenile offenders. Criminology, 49, 667-698.

Becker, G. (1968). Crime and punishment: an econometric approach. Journal of Political Economy, 76, 169-217.

Blackwood, L., Hopkins, N. \& Reicher, S. (2013). Turning the analytic gaze on "us": The role of authorities in the alienation of minorities. European Psychologist, 18, 245-252.

Bottoms, A., \& Tankebe, J. (2012). Beyond procedural justice: A dialogic approach to legitimacy in criminal justice. Journal of Criminal Law and Criminology, 102(1), 119-170.

Bradford, B. (2014). Policing and social identity: procedural justice, inclusion and cooperation between police and the public. Policing and Society, 24, 22-43.

Bradford, B., Hohl, K., Jackson, J. \& MacQueen, S. (2015). Obeying the rules of the road: Procedural justice, social identity and normative compliance. Journal of Contemporary Criminal Justice, 31, 171-191.

Bradford, B., Murphy, K. \& Jackson, J. (2014). Officers as mirrors: Policing, procedural justice and the (re)production of social identity. British Journal of Criminology, 54, 527-550.

Braithwaite, V. (Ed.) (2003). Taxing Democracy: Understanding Tax Avoidance and Evasion. Aldershot, UK: Ashgate.

Braithwaite, V., Schneider, F., Reinhart, M. \& Murphy, K. (2003). Charting the shoals of the cash economy. In V. Braithwaite (Ed.), Taxing Democracy: Understanding Tax Avoidance and Evasion. Aldershot, UK: Ashgate.

Braithwaite, J. (1989). Crime, shame and reintegration. Cambridge: Cambridge University Press.

Braithwaite, J. \& Makkai, T. (1994). Trust and compliance. Policing and Society, 4, 1-12.

Brunton-Smith, I., \& McCarthy, D. J. (2015). Prison Legitimacy and Procedural Fairness: A Multilevel Examination of Prisoners in England and Wales. Justice Quarterly, ahead-of-print, 1-26.

Doob, A. \& Webster, C. (2003). Sentencing severity and crime: Accepting the null hypothesis. Crime and Justice, 30, 143-195.

Farrington, D. (1991). Longitudinal research strategies: Advantages, problems and prospects. Journal of the American Academy of Child and Adolescent Psychiatry, 30, 369-374.

Gau, J. \& Brunson, R. (2010). Procedural justice and order maintenance policing: A study of inner-city young men's perceptions of police legitimacy. Justice Quarterly, 27, 255-279.

Gibbs, J. (1968). Crime, punishment and deterrence. Southwestern Social Science Quarterly, 48, 515-530.

Grasmick, H.G. \& Bursik, R. (1990). Conscience, Significant Others, and Rational Choice: Extending the Deterrence Model. Law \& Society Review, 24, 837-861.

Horne, C. (2009). A social norms approach to legitimacy. American Behavioral Scientist, 53, 400-415.

Huo, Y. (2003). Procedural justice and social regulation across group boundaries: Does subgroup identity undermine relationship-based governance? Personality and Social Psychology Bulletin, 29, 336-348.

Huo, Y., Smith, H., Tyler, T. \& Lind, E. (1996). Superordinate identification, subgroup identification, and justice concerns: Is separatism the problem; Is assimilation the answer? Psychological Science, 7 , $40-45$.

Jackson, J. \& Gau, J. (forthcoming, 2015). Carving up Concepts? Differentiating between Trust and Legitimacy in Public Attitudes towards Legal Authority. In Shockley, E., Neal, T., PytlikZillig, L. \& Bornstein, B. (eds.), Interdisciplinary Perspectives on Trust: Towards Theoretical and Methodological Integration. New York: Springer. 
Jackson, J., Bradford, B., Hough, M., Myhill, A., Quinton, P., \& Tyler, T. (2012a). Why do people comply with the law? Legitimacy and the influence of legal institutions, British Journal of Criminology, 52, 1051-1071.

Kagan, R. \& Scholz, J. (1984). The criminology of the corporation and regulatory enforcement strategies. In K. Hawkins \& J. Thomas (eds.), Enforcing regulation. Boston: Kluwer-Nijhoff Publishing.

Marshall, R., Smith, M. \& Armstrong, R. (1997). Self-assessment and the tax audit lottery: the Australian experience. Managerial Auditing Journal, 12, 9-15.

Mazerolle, L., Antrobus, E., Bennett, S. \& Tyler, T. (2013). Shaping citizen perceptions of police legitimacy: A randomized field trial of procedural justice. Criminology, 51, 33-63.

Mazerolle, L., Bennett, S., Antrobus, E. \& Eggins, E. (2012). Procedural justice, routine encounters and citizen perceptions of police: Main findings from the Queensland Community Engagement Trial. Journal of Experimental Criminology, 8, 343-367.

McAra, L. \& McVie, S. (2007). Youth justice? The impact of system contact on patterns of desistance from offending. European Journal of Criminology, 4, 315-345.

McCluskey, M., Mastrofski, S. \& Parks, R. (1999). To acquiesce or rebel: Predicting citizen compliance with police requests. Police Quarterly, 2, 389-416.

Murphy, B. \& Murphy, K. (2010). 'The Australian Survey of Tax Scheme Investors': Survey methodology and preliminary findings for the second stage follow-up survey. Alfred Deakin Research Institute Working Paper No 4. Geelong: Deakin University.

Murphy, B., Murphy, K. \& Mearns, M (2010). The Australian Tax System Survey of Tax Scheme Investors: Methodology and Preliminary Findings for the Third Follow-up Survey. Alfred Deakin Research Institute Working Paper No 13. Geelong: Deakin University.

Murphy, K. (2003). Procedural justice and tax compliance. Australian Journal of Social Issues, 38, 379408.

Murphy, K. (2005). Regulating more effectively: The relationship between procedural justice, legitimacy and tax non-compliance. Journal of Law and Society, 32, 562-589.

Murphy, K. (2013). Policing at the margins: Fostering trust and cooperation among ethnic minority groups. Journal of Policing, Intelligence and Counter Terrorism, 8, 184-199.

Murphy, K. \& Byng, K. (2002). A user's guide to the 'Australian Tax System Survey of Tax Scheme Investors'. Centre for Tax System Integrity Working Paper No. 39. Canberra: The Australian National University.

Murphy, K. \& Cherney, A. (2012). Understanding cooperation with police in a diverse society, British Journal of Criminology, 52, 181-201.

Murphy, K. \& Harris, N. (2007). Shaming, shame and recidivism: A test of reintegrative shaming theory in the white-collar crime context. British Journal of Criminology, 47, 900-917.

Murphy, K., Hinds, L., \& Fleming, J. (2008). Encouraging cooperation and public support for police. Policing and Society, 18, 138-157.

Murphy, K., Sargeant, E. \& Cherney, A. (2015). The importance of procedural justice and police performance in shaping intentions of cooperate with police: Does social identity matter? European Journal of Criminology, ahead of print.

Murphy, K., Tyler, T. R., \& Curtis, A. (2009). Nurturing regulatory compliance: Is procedural justice effective when people question the legitimacy of the law?. Regulation \& Governance, 3(1), 1-26.

Nagin, D. (2013). Deterrence in the Twenty-first century. Crime and Justice, 42, 199-263.

Paternoster, R. \& Piquero, A. (1995). Reconceptualizing deterrence: An empirical test of personal and vicarious experiences. Journal of Research in Crime and Delinquency, 32, 251-286.

Papachristos, A., Meares, T. \& Fagan, J. (2012). Why do criminals obey the law? The influence of legitimacy and social networks on active gun offenders. Journal of Criminal Law and Criminology, $102,397-440$.

Paternoster, R., Brame, R., Bachman, R., \& Sherman, L. (1997). Do fair procedures matter? The effect of procedural justice on spouse assault. Law and Society Review, 31, 163-204.

Piquero, A., Fagan, J., Mulvey, E., Steinberg, L. \& Odgers, C. (2005). Developmental trajectories of legal socialization among serious adolescent offenders. Journal of Criminal Law and Criminology, 96, 267-298.

Pratt, T., Cullen, F., Blevins, K., Daigle, L. \& Madensen, T. (2008). The empirical status of deterrence theory: A meta-analysis. In F. Cullen, J. Vright \& K. Blevins (eds), Taking Stock: The status of criminological theory Vol 15 (pp 367-396), New Jersey: Transaction Publishers.

Reisig, M., Bratton, J. \& Gertz, M. (2007). The construct validity and refinement of process-based policing measures. Criminal Justice and Behavior, 34, 1005-1028. 
Reisig, M. \& Mesko, G. (2009). Procedural justice, legitimacy and prisoner misconduct. Psychology, Crime and Law, 15, 41-59.

Reisig, M., Tankebe, J. \& Mesko, G. (2014). Compliance with the law in Slovenia: The role of procedural justice and police legitimacy. European Journal of Crime and Policy Research, 20, 259-276.

Slemrod, J., Blumenthal, M. \& Christian, C. (2001). Taxpayer response to an increased probability of audit: evidence from a controlled experiment in Minnesota. Journal of Public Economics, 79, 455483.

Sunshine, J. \& Tyler, T. (2003). The role of procedural justice and legitimacy in shaping public support for policing. Law and Society Review, 37, 513-548.

Sykes, G. \& Matza, D. (1957). Techniques of neutralization: A theory of delinquency. American Sociological Review, 22, 664-670.

Tajfel, H. \& Turner, J. (2001). An integrative theory of intergroup conflict. In M. Hogg \& D. Abrams (Eds). Intergroup relations: Essential readings. Key readings in social psychology (pp.94-109). New York, NY: Psychology Press.

Tankebe, J. (2009). Self-help, policing, and procedural justice: Ghanaian vigilantism and the rule of law. Law and Society Review, 43, 245-270.

Tankebe, J. (2013). Viewing things differently: the dimensions of public perceptions of police legitimacy. Criminology, 51, 103-135.

Tittle, C. (1969). Crime rates and legal sanctions. Social Problems, 16, 409-423.

Tyler, T. (1990). Why people obey the law. New Haven: Yale University Press.

Tyler, T. (2006). Psychological perspectives on legitimacy and legitimation. Annual Review of Psychology, 57, 375-400.

Tyler, T. \& Blader, S. (2003). Procedural justice, social identity and cooperative behavior. Personality and Social Psychology Review, 7, 349-361.

Tyler, T. \& Jackson, J. (2013). Future challenges in the study of legitimacy and criminal justice. In Tankebe, J. \& Liebling, A. (eds.) Legitimacy and Criminal Justice: An International Exploration. Oxford: Oxford University Press, pp. 83-104.

Tyler, T. \& Jackson, J. (2014). Popular legitimacy and the exercise of legal authority: Motivating compliance, cooperation and engagement. Psychology, Public Policy and Law, 20, 78-95.

Wenzel, M. (2004). The social side of sanctions: Personal and social norms as moderators of deterrence. Law and Human Behavior, 28, 547-567.

Wenzel, M. (2005). Motivation or rationalisation? Causal relations between ethics, norms and tax compliance. Journal of Economic Psychology, 26, 491-508.

Wenzel, M. (2006). A Letter from the Tax Office: Compliance Effects of Informational and Interpersonal Justice. Social Justice Research, 19, 345-364.

Wiley, S. \& Esbensen, F. (2013). The effect of police contact: Does official intervention result in deviance amplification? Crime and Delinquency. Published online 12 July 2013, doi: 10.1177/0011128713492496.

Williams, K. \& Hawkins, R. (1986). Perceptual research on general deterrence: A critical review. Law and Society Review, 20, 545-572. 


\section{Appendix}

Table A1. Confirmatory Factor Analysis for concepts used in Figure 1, and basic descriptive statistics for latent variables (* reverse coded to create scale).

\begin{tabular}{|c|c|}
\hline Concepts and measures & $\begin{array}{r}\text { Standardized } \\
\text { Factor Loadings }\end{array}$ \\
\hline Wave 1 measures & \\
\hline \multicolumn{2}{|l|}{ Procedural Justice (Mean=2.19; SD=0.69; $\alpha=0.88)$} \\
\hline The Tax Office treats people as if they can be trusted to do the right thing & .67 \\
\hline The Tax Office respects the individual's rights as a citizen & .71 \\
\hline The Tax Office gives equal consideration to the views of all Australians & .65 \\
\hline $\begin{array}{l}\text { The Tax Office consults widely about how they might change things to make it } \\
\text { easier for taxpayers to meet their obligations }\end{array}$ & .71 \\
\hline The Tax Office is concerned about protecting the average citizen's rights & .80 \\
\hline $\begin{array}{l}\text { The Tax Office considers the concerns of average citizens when making } \\
\text { decisions }\end{array}$ & .85 \\
\hline The Tax Office cares about the position of taxpayers & .86 \\
\hline The Tax Office gets the kind of information it needs to make informed decisions & .52 \\
\hline The Tax Office tries to be fair when making their decisions & .80 \\
\hline $\begin{array}{l}\text { The Tax Office goes to great lengths to consult with the community over } \\
\text { changes to their system }\end{array}$ & .65 \\
\hline \multicolumn{2}{|l|}{ Wave 2 measures } \\
\hline \multicolumn{2}{|l|}{ ATO Legitimacy $($ Mean=2.27; SD=0.71; $\alpha=0.67)$} \\
\hline The ATO has too much power* & .68 \\
\hline $\begin{array}{l}\text { People should follow the decisions of the ATO even if they go against what they } \\
\text { think is right }\end{array}$ & .42 \\
\hline As a society we need more people willing to take a stand against the ATO* & .57 \\
\hline I respect the ATO & .85 \\
\hline \multicolumn{2}{|l|}{ Social identity (Mean=4.18; SD=0.51; $\alpha=0.74)$} \\
\hline What is important to you? The Australian community & .41 \\
\hline What do you feel pride in? Being a member of the Australian community & .42 \\
\hline What is important to you? Being an honest taxpayer & .94 \\
\hline What do you feel pride in? Being an honest taxpayer & .91 \\
\hline \multicolumn{2}{|l|}{ Stigmatization $($ Mean $=3.68 ; \mathrm{SD}=0.89 ; \alpha=0.90)$} \\
\hline $\begin{array}{l}\text { Did you think there was some kind of implication about the kind of person you } \\
\text { are? }\end{array}$ & .82 \\
\hline Did you feel as though you were treated as a bad person? & .94 \\
\hline $\begin{array}{l}\text { Did you feel you were treated as though you were likely to commit another } \\
\text { offence? }\end{array}$ & .90 \\
\hline $\begin{array}{l}\text { Did you feel as though negative judgments were made about what kind of } \\
\text { person you are? }\end{array}$ & .95 \\
\hline $\begin{array}{l}\text { Did you feel as though you were accepted as basically law abiding by the } \\
\text { ATO?* }\end{array}$ & .69 \\
\hline Did you feel as though you were treated as a trustworthy person?* & .63 \\
\hline Did you feel as though you were treated as a criminal? & .78 \\
\hline \multicolumn{2}{|l|}{ Taxpayer morality $($ Mean=3.93; SD=0.73; $\alpha=0.74)$} \\
\hline Do you think you should honestly declare cash earnings on your tax return? & .79 \\
\hline Do you think it is acceptable to overstate tax deductions on your tax return?* & .77 \\
\hline $\begin{array}{l}\text { Do you think working for cash-in-hand payments without paying tax is a trivial } \\
\text { offence?* }\end{array}$ & .75 \\
\hline $\begin{array}{l}\text { Do you think the government should actively discourage participation in the } \\
\text { cash economy? }\end{array}$ & .67 \\
\hline
\end{tabular}




\begin{tabular}{|l|c|}
\hline Risk of sanction (Mean=4.17; $\mathbf{S D}=\mathbf{0 . 9 3}$ ) & \\
\hline $\begin{array}{l}\text { What do you think the chances are that you will be caught claiming } \$ 5000 \text { as } \\
\text { work deductions when the expenses have nothing to do with work? }\end{array}$ & \\
\hline & Wave 3 measures \\
\hline & \\
\hline Compliance (Mean=4.08; SD=0.64; $\boldsymbol{\alpha}=\mathbf{0 . 8 1}$ ) & \\
\hline $\begin{array}{l}\text { Tell } \text { us how your experience with the Tax Office has affected your taxpaying } \\
\text { behavior..... }\end{array}$ & \\
\hline I now try to avoid paying tax as much as possible* & .58 \\
\hline I no longer declare all of my income* & .81 \\
\hline $\begin{array}{l}\text { I now use the tax system in a negative way to recoup the financial losses I have } \\
\text { incurred* }\end{array}$ & .83 \\
\hline I am now more defiant towards the ATO* & .77 \\
\hline I now look for ways to purposefully cheat the tax system* & .85 \\
\hline I now look for many ways to recoup my financial losses* & .66 \\
\hline & \\
\hline Chi-square $=\mathbf{1 2 9 9 . 5 3 , ~ d f ~}=\mathbf{6 8 0}, \mathbf{p}<. \mathbf{0 5}$ & \\
\hline RMSEA $=\mathbf{. 0 5}$ & \\
\hline CFI $=\mathbf{. 9 7}$ & \\
\hline TLI $=\mathbf{. 9 7}$ & \\
\hline
\end{tabular}


Table A2. Means and standard deviation scores for each measure. Also reported are the bivariate correlations between measures. * $p<0.05$

\begin{tabular}{lccccccccc}
\hline Scale/Variable & Mean & SD & $\mathbf{1}$ & $\mathbf{2}$ & $\mathbf{3}$ & $\mathbf{4}$ & $\mathbf{5}$ & $\mathbf{6}$ & $\mathbf{7}$ \\
\hline 1. Procedural Justice & 2.19 & .69 & 1 & $.57^{*}$ & .04 & $-.41^{*}$ & -.01 & -.05 & $.11^{*}$ \\
2. Legitimacy & 2.27 & .71 & & 1 & .01 & $-.37^{*}$ & .10 & -.07 & $.22^{*}$ \\
3. Social Identity & 4.18 & .51 & & & 1 & $.22^{*}$ & $.38^{*}$ & $.18^{*}$ & $.28^{*}$ \\
4. Stigmatization & 3.68 & .89 & & & & 1 & $.18^{*}$ & $.22^{*}$ & -.01 \\
5. Morality & 3.93 & .73 & & & & & 1 & $.12^{*}$ & $.30^{*}$ \\
6. Deterrence & 4.17 & .93 & & & & & & 1 & -.07 \\
7. Compliance & 4.08 & .64 & & & & & & & 1 \\
\hline
\end{tabular}




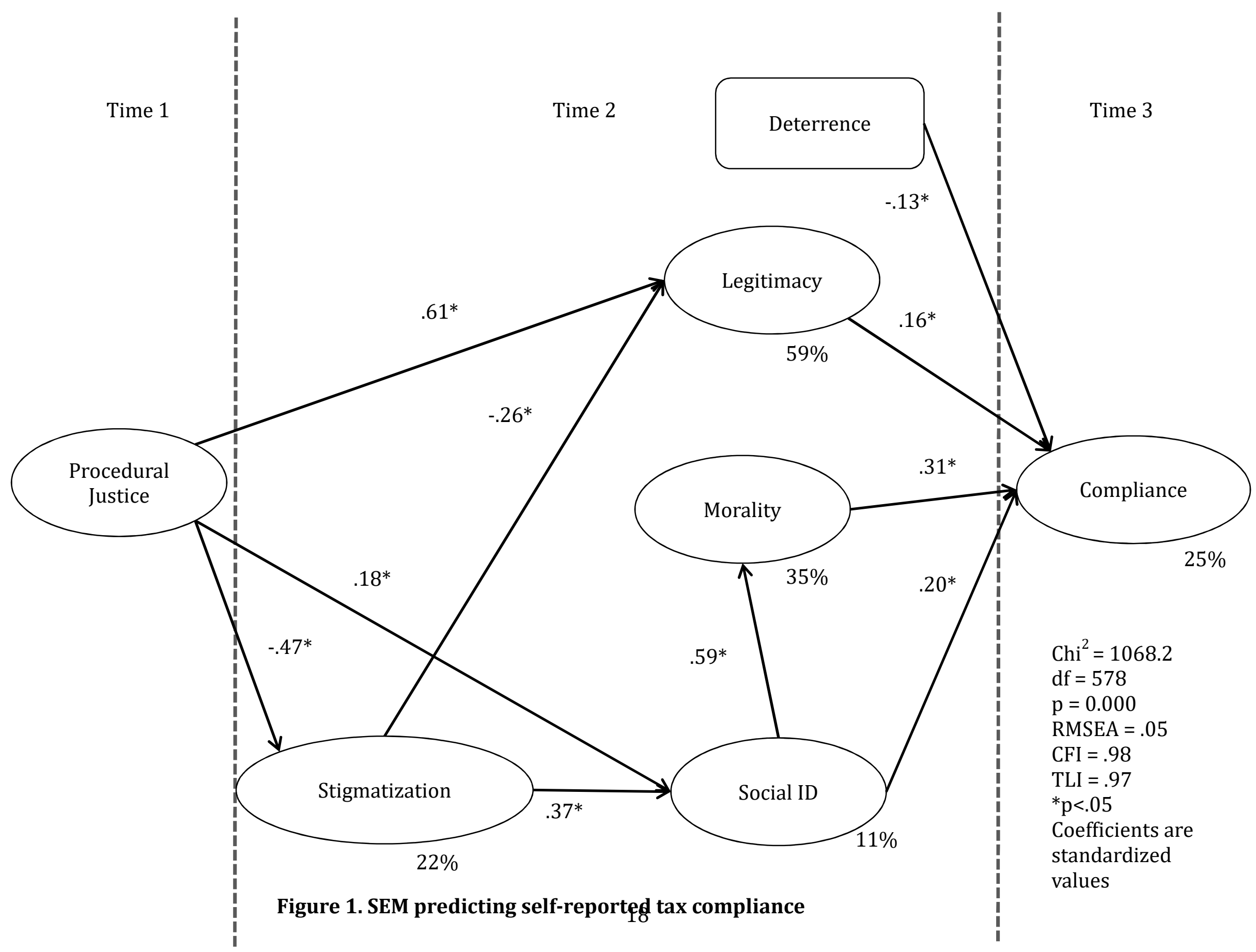

